\title{
Areal Extent of Erosion and Accretion in and around the Gahirmatha Coast, NW of Bay of Bengal by Remote Sensing and GIS Analysis of Multi-Temporal Satellite Imagery
}

\author{
Balabathina Veeraanarayanaa ${ }^{1}{ }^{*}$, Kandula Ravikumar ${ }^{2}$, Talluri Ramesh ${ }^{3}$, \\ Mopada Venkateswararao ${ }^{2}$, Pattam N. Sridhar ${ }^{4}$ \\ ${ }^{1}$ P.I, SYS-SERC, Department of Science \& Technology, New Delhi, India \\ ${ }^{2}$ Department of Geology, Andhra University, Waltair, India \\ ${ }^{3}$ Department of Geography, Andhra University, Waltair, India \\ ${ }^{4}$ National Remote Sensing Agency, Department of Space, ISRO, Hyderabad, India \\ Email: veera.sicom@gmail.com
}

Received 24 May 2015; accepted 19 July 2015; published 24 July 2015

Copyright (C) 2015 by authors and Scientific Research Publishing Inc.

This work is licensed under the Creative Commons Attribution International License (CC BY). http://creativecommons.org/licenses/by/4.0/

\section{(c) (i) Open Access}

\begin{abstract}
The shoreline morphology change due to erosion and deposition is a major concern for coastal zone management. In the present study, a highly dynamic coast of Gahirmatha on Bay of Bengal in northeast India is experiencing active erosion, which is mainly wave and tide erosion related hazard threat ending human habitation and sustainability of the coast. In our study, high resolution satellite imagery of time series provided detailed sequence of coastal morphology and their changes in all respects. Comparison study of relative shoreline positions on time series satellite data spanning three decades from 1973 to 2004 covering for the years of 1973, 1983, 1987, 1990, 1998, 2000 and 2004, provided regional changes with accelerated erosion and accretion. The result of the studies have revealed that the areas of severe erosion found along the coast are confined to the promontories of the present day mouths itself of the Baitrani at Dhamra and Brahmani at Maipura inlets. In this background, it is significant to understand the magnitude of factors that are responsible for prograding or retrograding of coast. The present study is an attempt in this direction.
\end{abstract}

\section{Keywords}

Accretion, Erosion, Morphology, Coast, Temporal Satellite Data

\footnotetext{
${ }^{*}$ Corresponding author.
} 


\section{Introduction}

The study of coastal geomorphology plays a vital role in understanding the nature of the coast and their sensitivity to coastal processes in terms of coastal erosion/accretion as a critical problem in the coastal zone as envisaged by CERC [1]. Coastal erosion and deposition depend upon a number of factors in combination, both natural and human-induced, that operate on different scales, such as total hydrologic regime namely tides, waves, winds, currents, shore face slope, and combination of vertical movement of land and sea level, cyclonic storms, sediment load, coastal structures and their stability, climate and vegetation, coastal engineering and geological structures, and innumerable spatio-temporal interactions [2]. The analysis of coastal dynamics and zones of accretion and erosion in long and short term scales is performed by using multi temporal and multi resolution satellite imageries which are highly useful for the planning and development of strategies for coast management.

\section{Study Area}

The Gahirmatha coast is the world's largest well known nesting ground of Olive Ridley turtles (i.e. Lepidochelys and Olivacea) located on the north of Orissa, East coast of India. Gahirmatha coast, in fact, a composite delta of the rivers named Brahmani and Baitarni having a "cuspate" forms the northern lobe of the Mahanadi delta. The study area of interest extends in the Dhamra, Maipura and Hansua tidal inlet channels of Brahmani-Baitarni rivers confluence on the Gahirmatha coast which in turn joins into the Bay of Bengal. The area of study is situated between $86^{\circ} 42^{\prime} \mathrm{E}, 20^{\circ} 30^{\prime} \mathrm{N}$ and $87^{\circ} 12^{\prime} \mathrm{E}, 20^{\circ} 54^{\prime} \mathrm{N}$ (Figure 1). The shoreline along the coast, spanning approximately $70 \mathrm{~km}$, is an area of constant transformation.

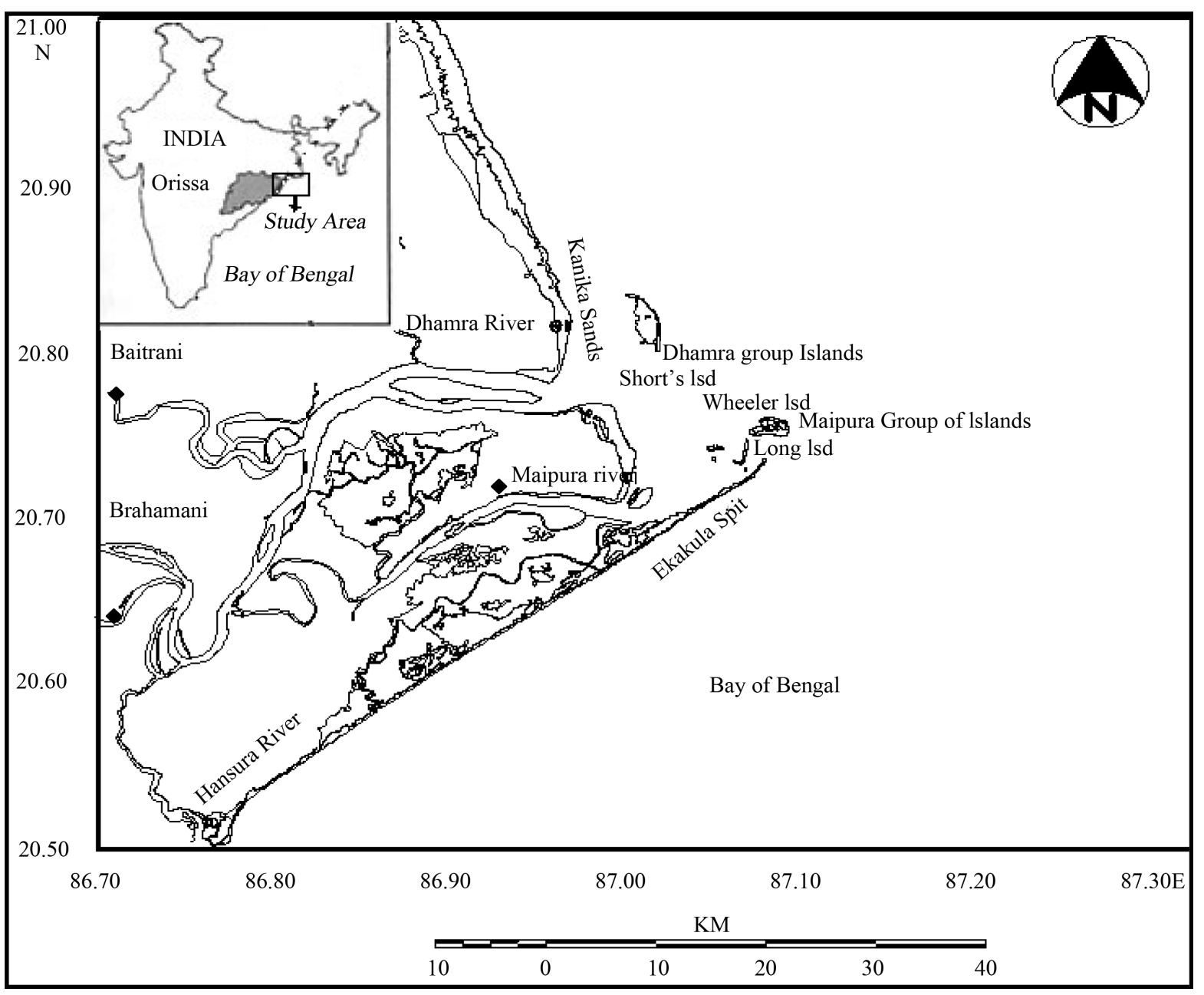

Figure 1. Map of Gahirmatha coast showing the study area for coastal erosion/accretion. 


\section{Materials and Methods}

In this study, various resolution of multi-temporal satellite sensor data such as Landsat-MSS/TM/ETM and IRS IC/ID-LISS III and IRS P6-LISS IV MX during the period from 1973 to 2003 (i.e. 1973, 1983, 1987, 1990, 1998, 2000, 2003 \& 2004 respectively) are used. The path \& row, spatial resolution of the pixel and spectral bands chosen for the study are mentioned in Table 1 . While selecting the above data sets evenness of all Mean High Tide Water Level (MHTWL) are well maintained, especially with the proximity of pre and post cyclone period of preceding years. All the satellite images are geographically corrected with reference to Survey of India Topographic maps of 1973 on a 1:50,000 scale for comparison by using ERDAS 9.2 software. The temporal changes along the deltaic coast are analysed by overlying the above mentioned seven imageries with reference to one another as well as topographic maps of SOI were taken as baseline reference study, 1) The areas of accretion or erosion along the coast are identified between every two consecutive dates of the period in respect of all the above data sets. Vector coverages were created for all the data sets at 1:25,000 map resolutions and maintaining the minimum root mean square (RMS) error (0.0001) while digitizing. Comparisons of features were differentiated by the developed spectral signatures in ERDAS software. All the created vector coverages are exported in to shape file for working on Arc GIS 9.1 platform. All the pseudo errors of arc, polygon, line and point attributes are corrected by the snap distance of $1 \times 10^{-8}$ in Arc Info 3.2 software and given common weightage or ID's for all the classification of morphological features. The area statistics for the zones of erosion or accretion were obtained by overlaying of any two layers using query method in Arc GIS tool and the significant changes occurred during the study period, it is mapped, combined and highlighted in the zones of erosion or accretion. The methodology adopted for thematic layer preparation, a process flow diagram is shown in Figure 2. 2) A traditional methodology for studying shoreline change, the baseline information of 1973 Survey of India topographic map, and the above selective temporal imageries between 1973 and 2003 were used to extract and digitize the layers of vector shoreline data along the coast about $70 \mathrm{~km}$. The corrected and generalized multi-temporal shorelines of coast were used in a classical transect based analysis of shore-normal movement using an Arc View GIS Extension named Digital Shoreline Analysis System (DSAS) developed by the United States Geological Survey (USGS). Transect lines along the coastline were created perpendicular to master line of 1973 at every $250 \mathrm{~m}$ interval using construct points tool in Editor Toolbar of ARC GIS. 3) Naval Hydrographic data used for decadal study of bottom topography of the nearshore at a given datum which are retransformed to the level of mean high tide level as the satellite data also follows the similar condition. 4) The major morphological features were classified and mapped by unsupervised and supervise classification, band ratio, and visual interpretation remote sensing techniques etc.

\section{Results and Discussions}

\subsection{Coastal Morphology Change}

Areal extent of erosion and accretion over a period 30 years are mapped from different multi-temporal satellite

\begin{tabular}{cccccc}
\multicolumn{7}{l}{ Table 1. The details of imageries/Maps/Toposheet used in the study. } \\
\hline Satellite/Sensor & Date of Pass & Spatial Resolution & Path/Row/No & Bands & Band with \\
\hline Landsat-1 MSS & Jan-17-1973 & $79 \mathrm{~m}$ & $149 / 36$ & $4[4,5,6,7]$ & $0.5-1.1 \mu \mathrm{m}$ \\
Landsat-4 MSS & Nov-10-1983 & $82 \mathrm{~m}$ & $139 / 46$ & $4[4,5,6,7]$ & $0.5-1.1 \mu \mathrm{m}$ \\
Landsat-5 TM & Jan-29-1987 & $30 \mathrm{~m}$ & $139 / 46$ & $7[1,2,3,4]$ & $0.45-0.9 \mu \mathrm{m}$ \\
Landsat-5 TM & Nov-21-1990 & $30 \mathrm{~m}$ & $139 / 46$ & $7[1,2,3,4]$ & $0.45-0.9 \mu \mathrm{m}$ \\
IRS-1C LISS-III & Feb-14-1998 & $23.5 \mathrm{~m}$ & $107 / 58$ & $4[2,3,4,5]$ & $0.52-1.7 \mu \mathrm{m}$ \\
Landsat-7 ETM & Oct-23-2000 & $15 \mathrm{~m}$ & $139 / 46$ & $7[1,2,3,4]$ & $0.5-0.9 \mu \mathrm{m}$ \\
IRS-1D LISS-III & Jan-04-2001 & $23.5 \mathrm{~m}$ & $107 / 58$ & $4[2,3,4,5]$ & $0.52-1.7 \mu \mathrm{m}$ \\
IRS-1D LISS-III & May-03-2003 & $23.5 \mathrm{~m}$ & $107 / 58$ & $4[2,3,4,5]$ & $0.52-1.7 \mu \mathrm{m}$ \\
IRS-P6 LISS-IV & Mar-01-2004 & $5.8 \mathrm{~m}$ & Orbit & $3[2,3,4]$ & $0.52-0.86 \mu \mathrm{m}$ \\
SOI Topo. Map & 1973 & & & & \\
NHO maps & 1973, 83, 92 \& 2002 & & 351,352 & & \\
\hline
\end{tabular}




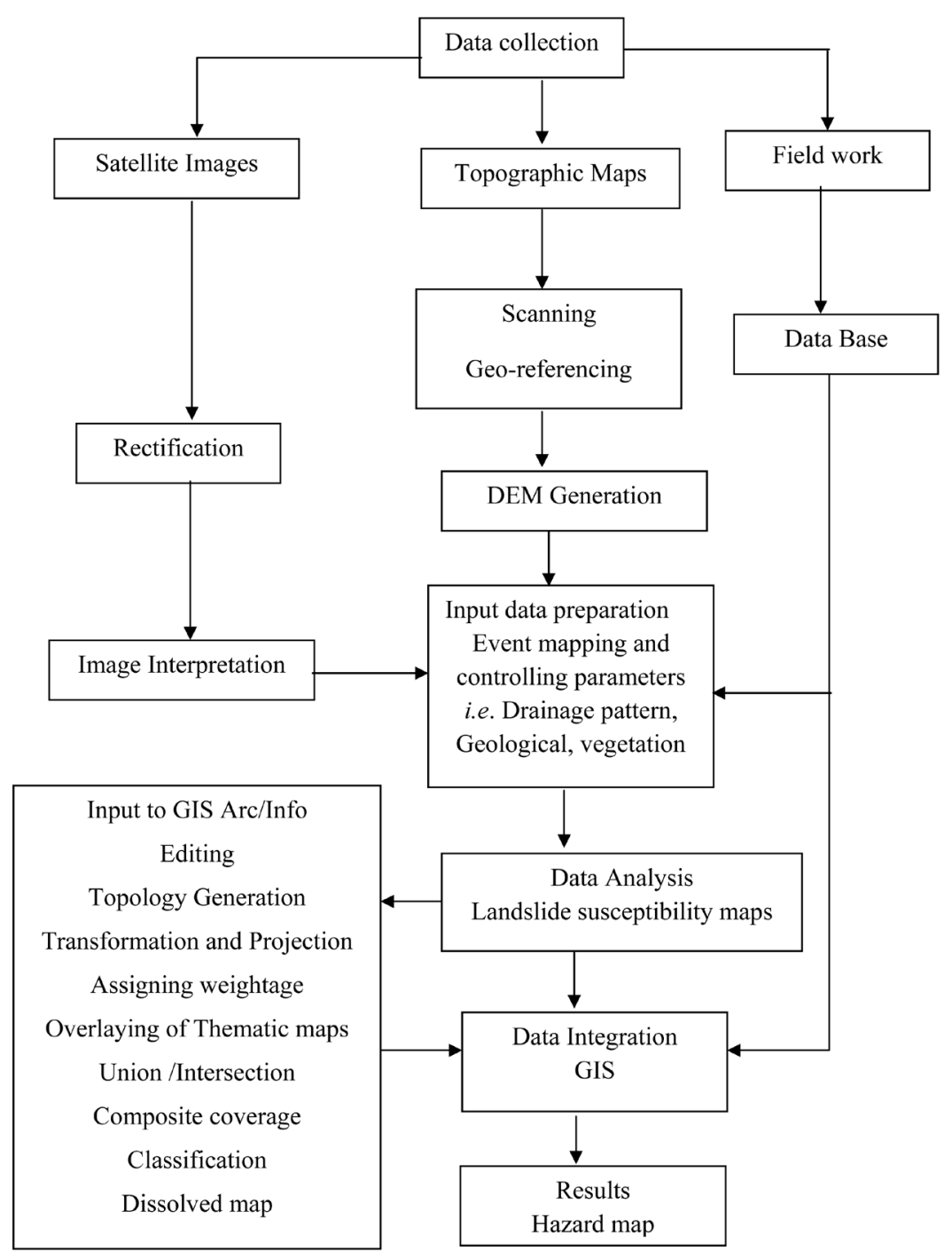

Figure 2. Methodology of thematic data layer preparation.

data and area statistics of the Gahirmatha coast of erosion and accretion is presented in Figure 3(a) and Table 2. The study revealed that there is a predominat net erosion coast of about $3.35 \mathrm{~km}^{2}$ rather than accretion from 1973-2003. However, the net change from 1973 to 1983 was $1.12 \mathrm{~km}^{2}$ at the rate of $0.11 \mathrm{~km}^{2} / \mathrm{yr}$ and $1.47 \mathrm{~km}^{2}$ at the rate of $0.37 \mathrm{~km}^{2} / \mathrm{yr}$ during $1983-1987$, however there was a trend of accretion about $0.3 \mathrm{~km}^{2}$ at the rate of $0.10 \mathrm{~km}^{2} / \mathrm{yr}$ for the period of $1987-1990$.

There was a severe erosion of $2.34 \mathrm{~km}^{2}$ at the rate of $0.29 \mathrm{~km}^{2} / \mathrm{yr}$ was noted during 1990-1998, and accretion of $0.65 \mathrm{~km}^{2}$ at the rate of $0.3 \mathrm{~km}^{2} / \mathrm{yr}$ during the period from 1998 to 2004 shown Figure 3(b). The net result of this cycle process left with a gain of $0.43 \mathrm{~km}^{2}$ due to accretion. The time series analysis of selective coast morphology features in Figure 4 shows that the formation of numerous islands, sand bars, channel bars and sandy shoals, and spit in ebb tidal region of Gahirmatha coast suggesting an active depositional phase shifting landward [3]. The morphological variations are oscillatory and episodic concurring with cyclone of 1973, 1982, 1985, 1988, 1997, 1999 and 2002. There was a gradual increase in the rate erosion from 1973-1998 at the inlet mouth of Dhamra River and transportation of sediment offshore forming sheltered islands, and Shoals. Off late, the trend changed to gradual accretion due to the fluvial discharge laden with sediment. The study indicated two distinct trends of geomorphic process on either side of the Dhamra river mouth. Nearshore coastal process and cyclone largely control shoreface modification of the beaches and sand bars to the south of the river mouth, whereas islands in this region modify geomorphic processes of the ebb tidal delta to the north of the river mouth. 


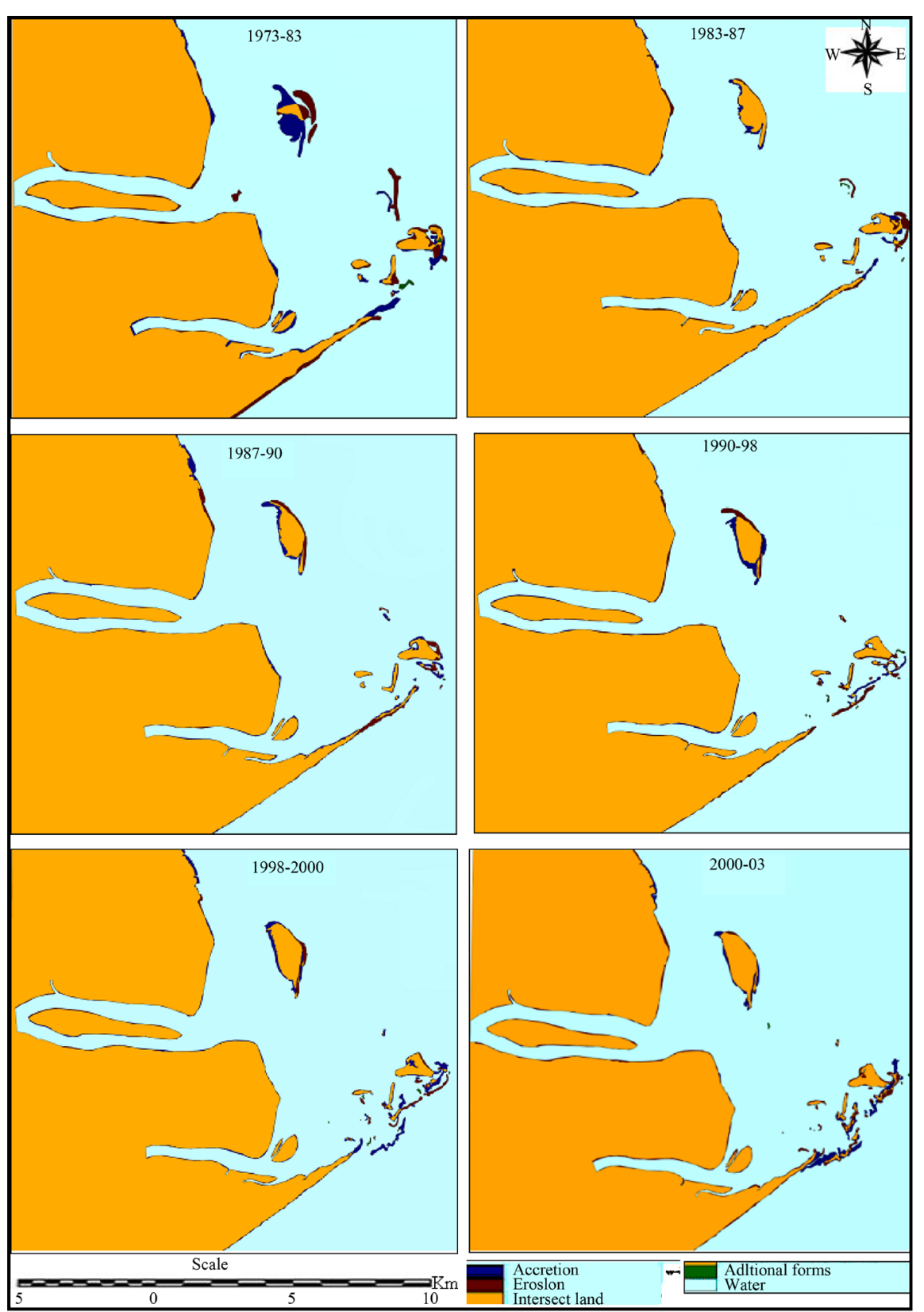

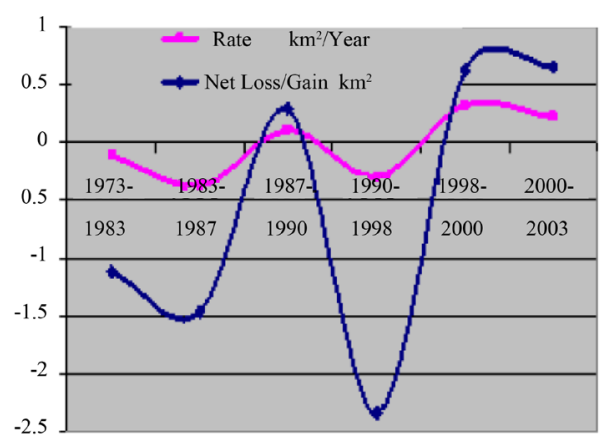

(a)

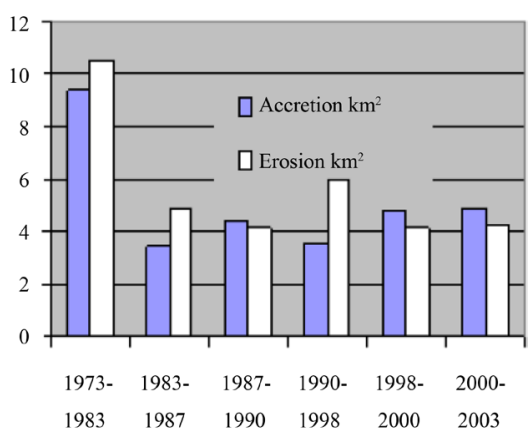

(b)

Figure 3. (a) Maps showing areas of erosion/accretion along the coast emerged and; (b) graphs indicate its rate of change of erosion/accretion. 


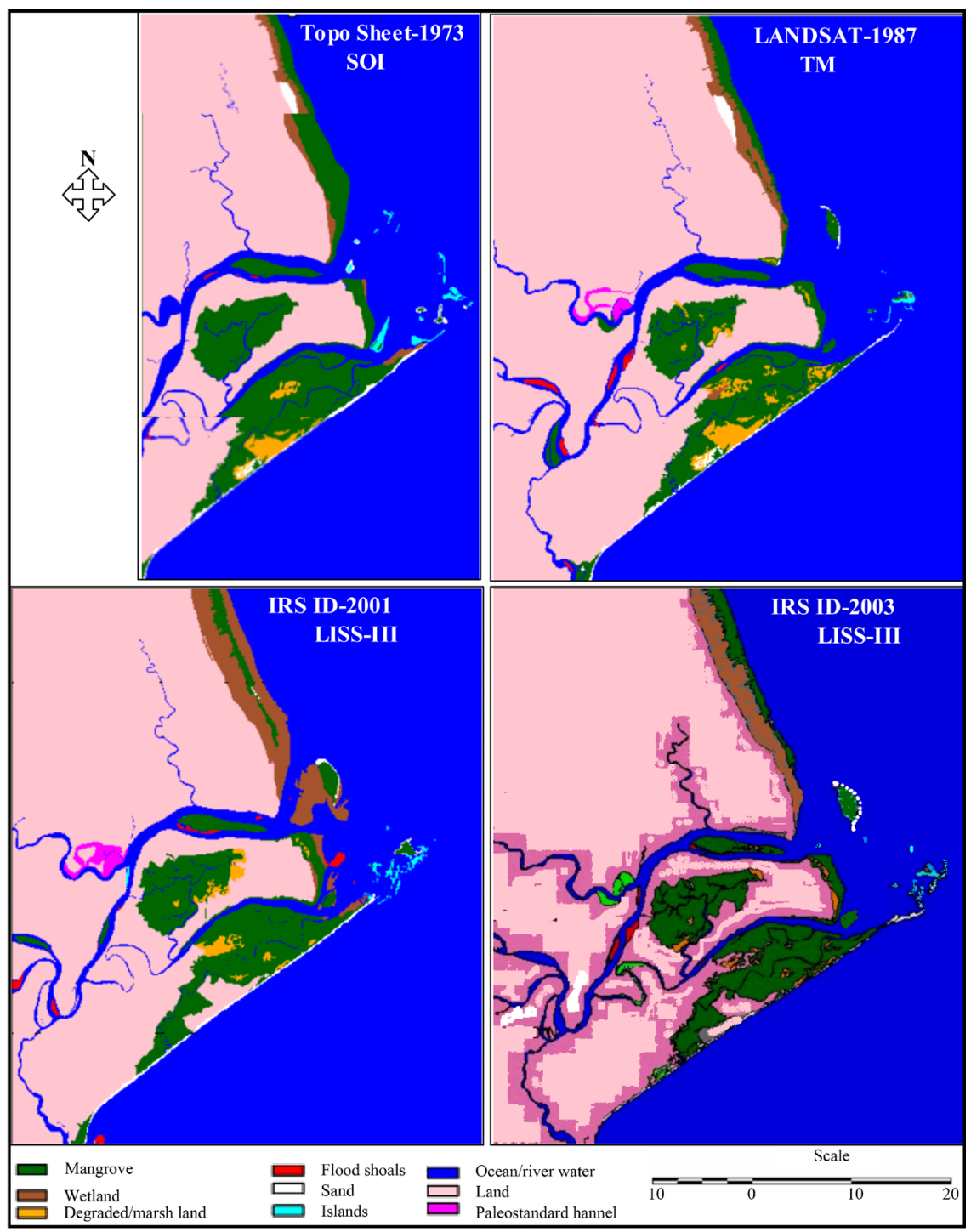

Figure 4. Morphological changes of coast during 1973-2003.

Table 2. Area of change Erosion-Accretion along the coast emerged.

\begin{tabular}{cccccc}
\hline Period (Years) & Accretion $\left(\mathrm{Km}^{2}\right)$ & $\begin{array}{c}\text { Erosion } \\
\left(\mathrm{Km}^{2}\right)\end{array}$ & $\begin{array}{c}\text { Additional } \\
\text { formations }\left(\mathrm{Km}^{2}\right)\end{array}$ & Net Loss/Gain $\left(\mathrm{Km}^{2}\right)$ & Rate of change $\left(\mathrm{Km}^{2} / \mathrm{yr}\right)$ \\
\hline $1973-1983$ & 9.39 & 10.51 & 0.011 & -1.12 & 0.11 \\
$1983-1987$ & 3.46 & 4.93 & 0.084 & -1.47 & 0.37 \\
$1987-1990$ & 4.43 & 4.13 & 0.014 & +0.30 & -2.34 \\
$1990-1998$ & 3.58 & 5.92 & 0.152 & +0.63 & 0.10 \\
$1998-2000$ & 4.80 & 4.17 & 0.121 & +0.65 & 0.32 \\
$2000-2003$ & 4.92 & 4.27 & 0.051 & -3.35 & 0.22 \\
Total of 30yrs & 30.58 & 33.93 & 0.433 & 0.12 \\
\hline
\end{tabular}

Northerly drift prevailing during the SW monsoon season and also during December to February favors spit and sand bar growth from south to north, whereas the southerly drift during September to December (post monsoon) and during pre-monsoon is responsible for erosion of the portion of the beach to the north of the river mouth. 


\subsection{Modifications of Coastal Landforms}

The most of severe cyclonic events occurred during NE monsoon over the Gahirmatha coast were responsible for dramatic modifications of the in and around the landscape [4]. These historical cyclones of 1973, 1982, 1985, 1988, 1997, 1999 and 2002 resulted storm surge of high waves on the sandy beaches drawing large volume silt and sand due to dune breach, over wash, sand bar migration, spit dynamics, inlet changes/outlet formation. This is associated with the heavy run off from Ganges, Brahmaputra and Mahanadi into the estuaries depositing enormous sand and silt during violent storms. The ebb current velocity is more than flood current velocity which takes the lighters farther out into the sea to increase suspended sediment. In the past three decades, mechanical reworking on the lonshore transported sediment by breaking waves is evident from Ebb deltaic region [5]. The coast is semi-diurnal macro tidal with an amplitude about $(\sim 4.5 \mathrm{mt})$ allows farther out into the land since the shallow foreshore blanks. Under certain level of stable tectonic and sea level rise tends to shift the sediment away from coast causing coastal erosion [6]. But the rate of transportation is very poor based on the analysis of texture characteristics, it was mechanically reworked by tides, tidal currents, waves and alongshore currents [7].

Sediment dynamics at ebb tidal delta is subject to cyclic morphological changes. Descriptions of the resulting sediment flux elucidate an offshore directed sediment transport for both tides are cyclic i.e., clockwise and counterclockwise around the composite ebb delta [8]. The bottom topographic and bathymetric volume change gives an understanding to infer sediment pathways and flux of sediment. The net changes (erosion/accretion) of landforms during 1973-2003 are shown in Table 3.

\subsection{Suspended Sediment Dynamics of the Coast}

The coarse grain sediment (sand) of the shore is settling rapidly to the ocean floor, to be shifted around by coastal-ocean currents (flood and ebb tidal currents) and waves forming beaches and other coastal landforms, or carried offshore into deeper water by turbidity currents such that the sediment is permanently removed from the coastal system. Smaller sediment grains (silt and clay) have much slower settling velocities, so they tend to be carried suspended within the water column for some time before settling onto the ocean floor as the ebb current velocity $(1-1.5 \mathrm{~m} / \mathrm{s})$ is more than flood current velocity $(1.0 \mathrm{~m} / \mathrm{s})$. The Ocean Color Monitor (OCM) onboard Oceansat data derived suspended sediment concentration in Figure 5, showing from 60 - > $200 \mathrm{mg} / \mathrm{l}$ and following the landward shallow bathymetry level of concentration is high.

\subsection{Shoreline Changes Analysis}

Approximately, $70 \mathrm{~km}$ long shorelines are effectively divided into 280 discrete transects, at which DSAS estimated the landward and seaward changes of the shoreline in different periods. Shoreline changes along these

Table 3. The net changes (erosion/accretion) of landforms during 1973-2003.

\begin{tabular}{ccccc}
\hline \multirow{2}{*}{ Land form } & \multicolumn{2}{c}{ 1973-1987 } & \multicolumn{2}{c}{$1987-2003$} \\
\cline { 2 - 5 } & Area $\left(\mathrm{km}^{2}\right)$ & Outer Limits $(\mathrm{km})$ & Area $\left(\mathrm{km}^{2}\right)$ & Outer Limits $(\mathrm{km})$ \\
\hline Bhadruka Island & 2.32 & 2.93 & 1.52 & 0.16 \\
Short's Island & -0.52 & -5.05 & -0.05 & 0.16 \\
Wheeler Island & -0.29 & -5.18 & -0.62 & -0.17 \\
Longer Island & -0.11 & 0.15 & -016 & -0.42 \\
Sand Bar & 0.02 & 1.60 & -0.17 & 0.25 \\
Swash Bar & 0.02 & 0.31 & -0.15 & 0.02 \\
Coconut Island & -0.13 & -0.23 & -0.14 & -0.52 \\
Small Wheeler Is & -0.07 & 0.87 & -0.05 & -0.15 \\
Dhamra Inlet & -0.05 & -0.12 & -0.02 & 0.29 \\
Maipur Inlet & 0.41 & 0.30 & 0.28 & $-3.54 \& 0.02$ \\
Spit Geometry & Length \& Width & $+3.16 \&-0.13$ & Length \& Width \\
\hline
\end{tabular}




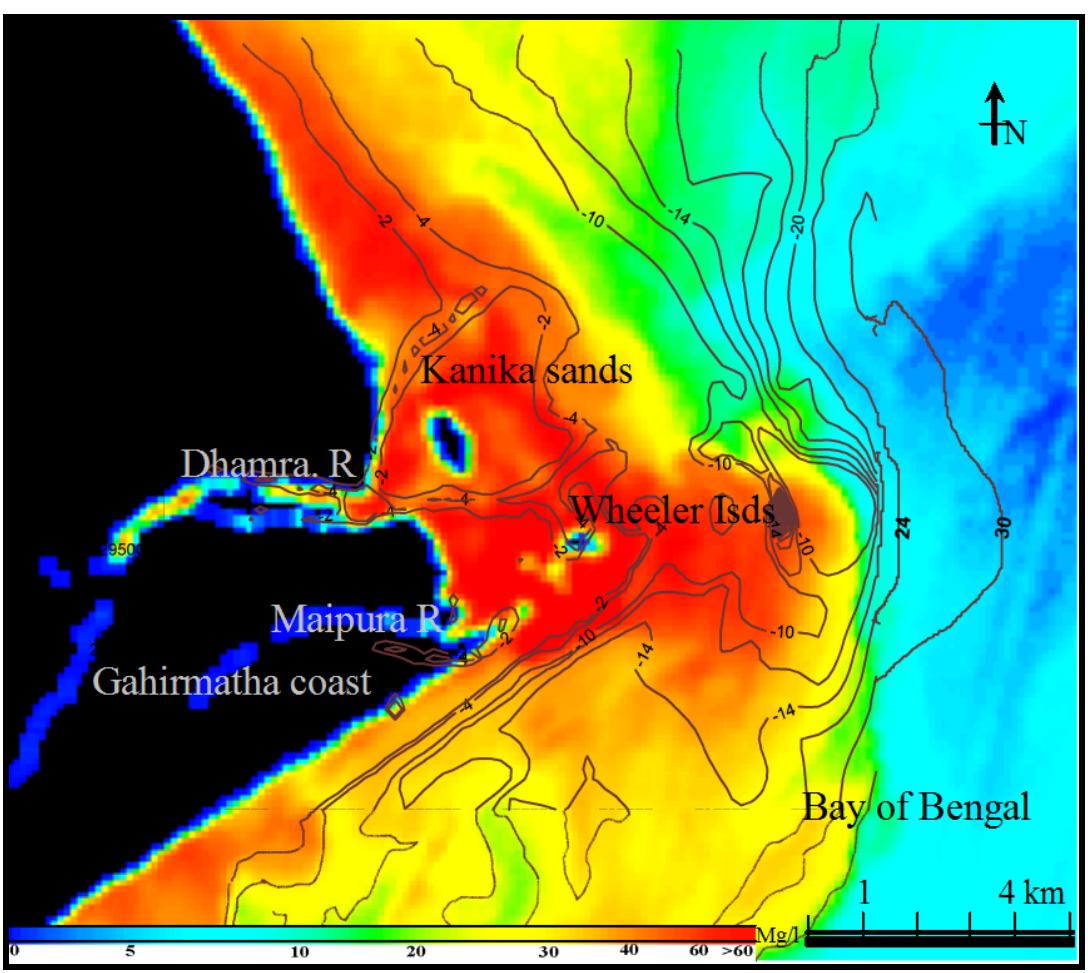

Figure 5. IRS P4 (Oceansat-1), OCM derived Suspended sediment flux overlaid by shallow bathymetry.

transect is computed. A detailed signature of the shoreline movement at every $250 \mathrm{mt}$ interval all along the coast (Dhamra north, Maipura north and Maipura south, Ekakula beach) is shown in Figure 6. GIS analysis of shoreline data reveals a complicated scenario of localized and periodic erosion and accretion along the coast. A cumulative shoreline migration over the past three decades (1973-2003) is also shown in Figure 7, wherein generally eroding at inlet mouths with some sporadic accretion in north shoreline correspondingly shifting landward in south. Movement of shoreline was spatially and temporally variable. Nevertheless, there were conspicuous alternate regimes of accretion; as an example in periodic regime of 1987-2003 and a spell of erosion all along the coast with some sporadic accretion. Apparent episodic trends of erosion-accretion are captured in longer time intervals 1973-1987, 1990-1998 and in shorter intervals 1987-1990, 1998-2000, 2000-2003 and there was distinct pattern. With this, the coastline was experienced a periodic changes during the study period and also the coastline erosion occurred primarily due to episodic high wave energy, natural changes in the coastal ecosystem, and as a consequence of human activities [9]. The shoreline experience two periods of accretion, one during May to early September (SW monsoon) and another during December to February followed by two periods of erosion, one during September to December (NE monsoon) and another a minor phase of erosion from February to April.

\subsection{The Intertidal Areas of the Coast}

The role of inter tidal flats is of primary importance, as they can act as dynamic coastal defenses. Trenhaile [10] defines the intertidal foreshore or beach face as "extending from the crest of the berm, or upper limit of uprush at the high tide level, to the ordinary low tide level”. In the present context of Sea-Level Rise, it recently quantified by the IPCC, 2001 [11] in the order of $0.88 \mathrm{~m}$ by the year 2100. Results from the statistical quantifications shown in Table 4 and field analysis revealed that, the intertidal areas are extending further landward due to low gradient, seaward sloping causing sink at inlet mouths, whereas, the coast is depositional, but still the shoreline is shifting landward. The penetration of surge storm surge water travel longer distance in to plain land with low surface slopes compared to plain land with moderate slopes. Comparing from the multi temporal data in the present observations of 1998, 2000 and 2004, it is understood that a gradual increase in the width of exposed 

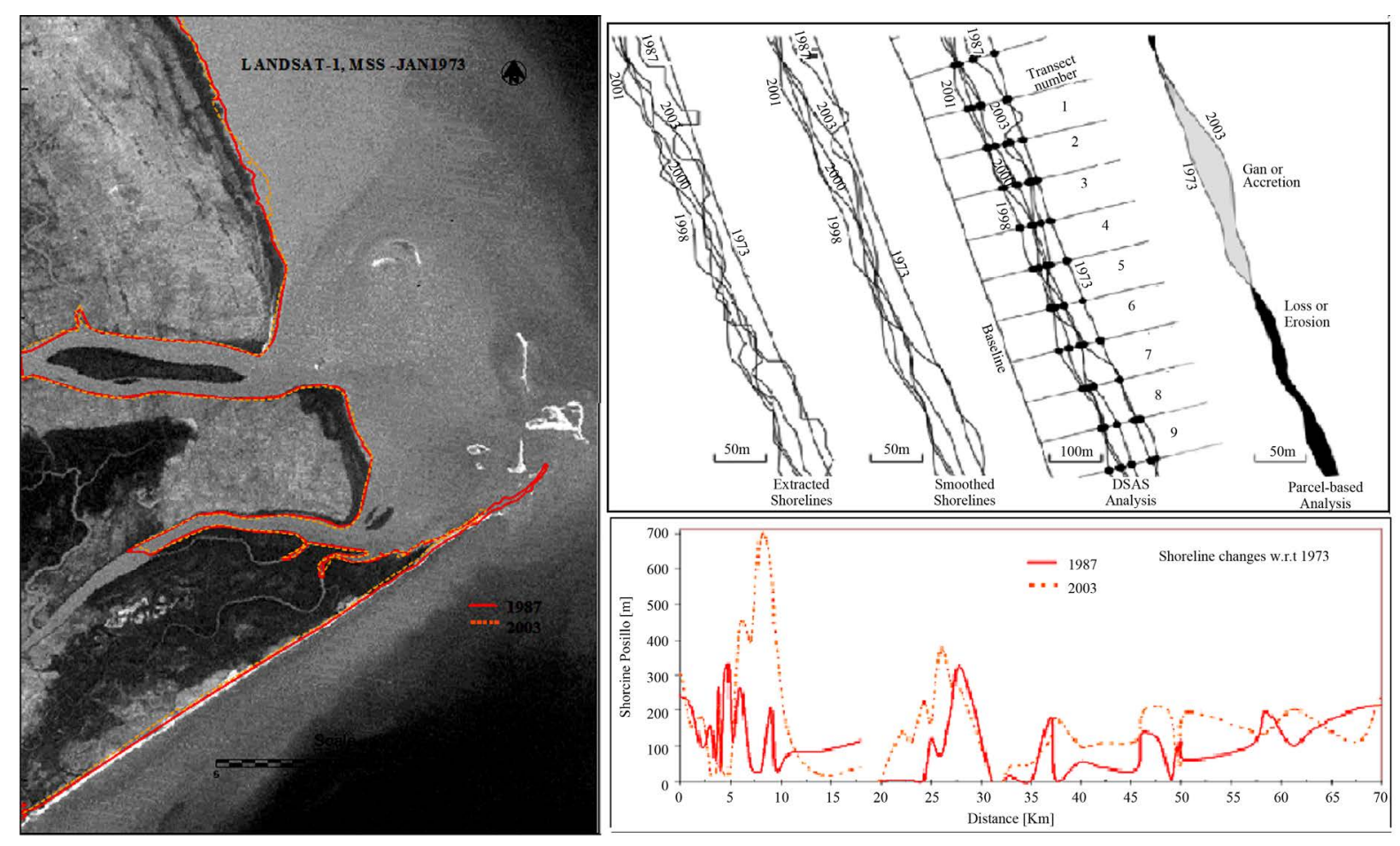

Figure 6. Multi-temporal shorelines of a section of Gahirmatha coast showing thematics of Digital Shoreline Analysis System (DSAS) and Parcel-based analysis for long \& short term change.

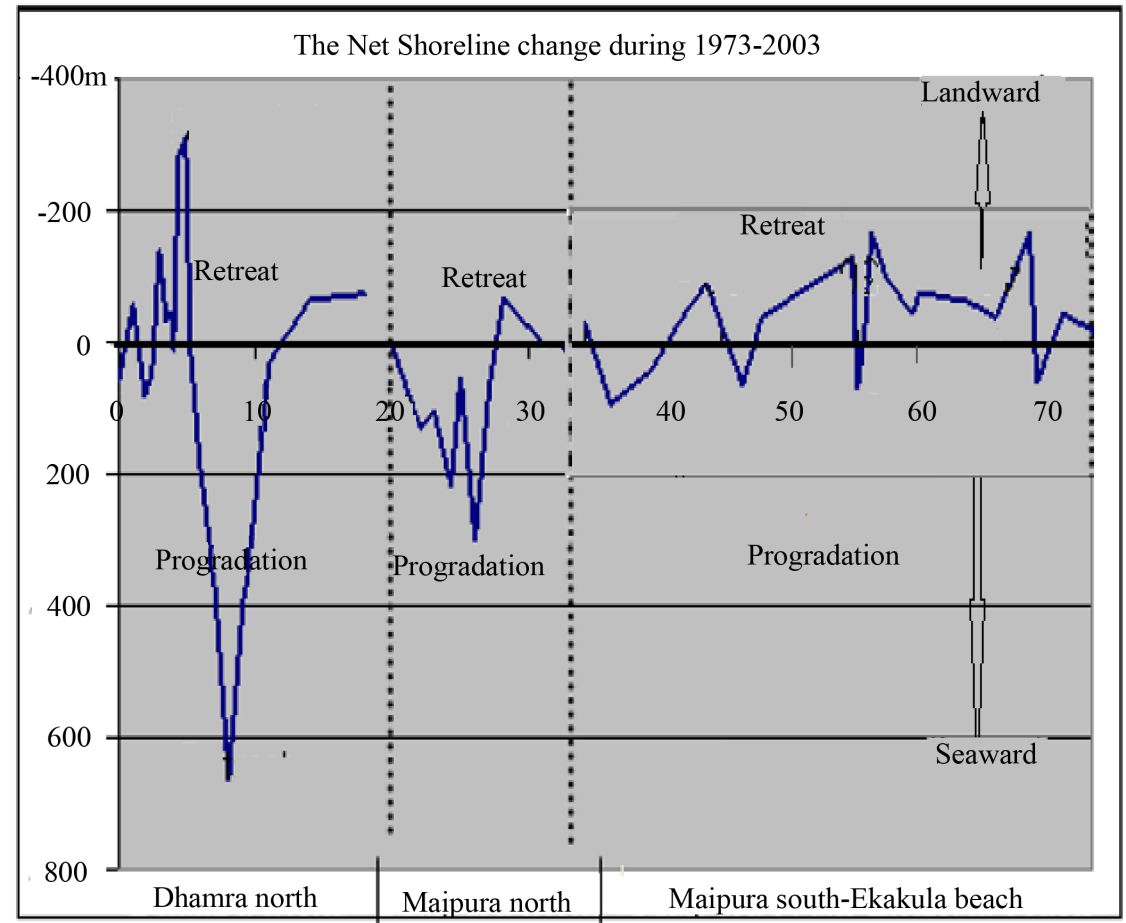

Figure 7. Cumulative over shoreline change of coast.

intertidal region of about avg. $1.3 \mathrm{~km}$, wherein, the coast encounter area of severe erosion just upright at the mouth forming deep underwater channel northward due to macro tide condition (0.3 - $4.5 \mathrm{mt})$. The southern part of Maipura group (Figure 8) is acting as sink due to the developing ebb channels and down drift deposition pose 


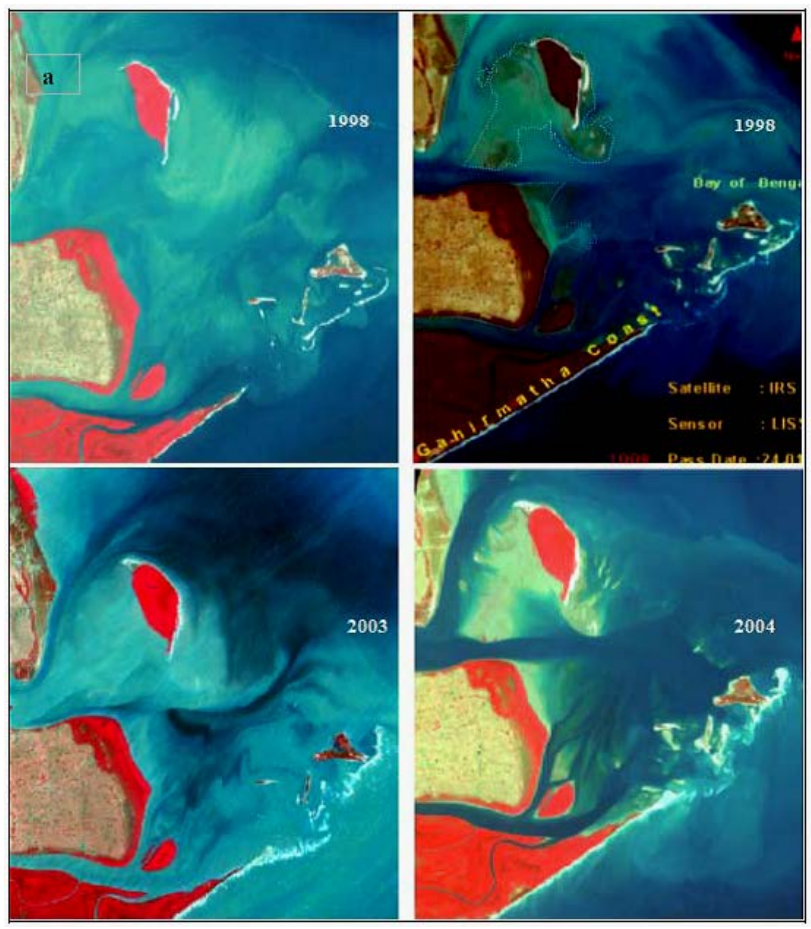

Figure 8. Inter-tidal zones of coast during Low-high tide from satellite data.

Table 4. Statistics of intertidal variation of area domain at various tide.

\begin{tabular}{|c|c|c|c|c|c|c|c|c|c|c|c|c|}
\hline \multirow{2}{*}{$\begin{array}{l}\text { Area of } \\
\text { Interest }\end{array}$} & \multicolumn{2}{|c|}{$\begin{array}{l}\text { During Ebb tide } \\
\text { of year } 1998\end{array}$} & \multicolumn{2}{|c|}{$\begin{array}{c}\text { During Flood } \\
\text { tide of year } 1998\end{array}$} & \multicolumn{2}{|c|}{$\begin{array}{l}\text { During Ebb tide } \\
\text { of year } 2001\end{array}$} & \multicolumn{2}{|c|}{$\begin{array}{l}\text { During Flood tide } \\
\text { of year } 2001\end{array}$} & \multicolumn{2}{|c|}{$\begin{array}{l}\text { During Ebb tide } \\
\text { of year } 2003\end{array}$} & \multicolumn{2}{|c|}{$\begin{array}{l}\text { During Flood } \\
\text { tide of year } 2003\end{array}$} \\
\hline & $\begin{array}{l}\text { Area(in } \\
\mathrm{km}^{2} \text { ) }\end{array}$ & $\begin{array}{l}\text { Peri(in } \\
\text { km) }\end{array}$ & $\begin{array}{l}\text { Area(in } \\
\mathrm{km}^{2} \text { ) }\end{array}$ & $\begin{array}{l}\text { Peri(in } \\
\text { km) }\end{array}$ & $\begin{array}{l}\text { Area(in } \\
\mathrm{km}^{2} \text { ) }\end{array}$ & $\begin{array}{l}\text { Peri(in } \\
\mathrm{km} \text { ) }\end{array}$ & $\begin{array}{l}\text { Area(in } \\
\mathrm{km}^{2} \text { ) }\end{array}$ & $\begin{array}{l}\text { Peri(in } \\
\text { km) }\end{array}$ & $\begin{array}{l}\text { Area(in } \\
\mathrm{km}^{2} \text { ) }\end{array}$ & $\begin{array}{l}\text { Peri(in } \\
\text { km) }\end{array}$ & $\begin{array}{l}\text { Area(in } \\
\mathrm{km}^{2} \text { ) }\end{array}$ & $\begin{array}{c}\text { Peri(in } \\
\text { km) }\end{array}$ \\
\hline \multirow{2}{*}{$\begin{array}{l}\text { Kannika } \\
\text { sands } \\
\text { intertidal } \\
\text { area }\end{array}$} & 23.4 & 27.86 & 4.89 & 9.85 & 25.44 & 29.96 & 4.95 & 10.11 & 24.3 & 26.67 & 5.45 & 11.18 \\
\hline & \multicolumn{4}{|c|}{ Width (in km) } & \multicolumn{2}{|c|}{ Width (in km) } & & & \multicolumn{2}{|c|}{ Width (in km) } & & \\
\hline $\begin{array}{c}\text { Dhamra } \\
\text { intertidal } \\
\text { area }\end{array}$ & \multicolumn{2}{|c|}{1.321} & & & \multicolumn{2}{|c|}{1.331} & & & \multicolumn{2}{|c|}{1.310} & & \\
\hline $\begin{array}{l}\text { Maipura } \\
\text { intertidal } \\
\text { area }\end{array}$ & \multicolumn{2}{|c|}{0.985} & & & \multicolumn{2}{|c|}{0.978} & & & \multicolumn{2}{|c|}{0.910} & & \\
\hline $\begin{array}{c}\text { Ekakula } \\
\text { Intertidal } \\
\text { area }\end{array}$ & \multicolumn{2}{|c|}{0.245} & & & \multicolumn{2}{|c|}{0.258} & & & \multicolumn{2}{|c|}{0.269} & & \\
\hline \multirow{2}{*}{$\begin{array}{l}\text { Decadal } \\
\text { change } \\
\text { (in Ha) }\end{array}$} & \multicolumn{2}{|c|}{$1972-1983$} & \multicolumn{2}{|c|}{$1982-1992$} & \multicolumn{2}{|c|}{$1992-2002$} & & & & & & \\
\hline & \multicolumn{6}{|c|}{ Volumetric analysis from Naval hydrographs } & & & & & & \\
\hline $\begin{array}{l}\text { Ebb shoal } \\
\text { area }\end{array}$ & \multicolumn{2}{|c|}{1368} & \multicolumn{2}{|c|}{-402} & \multicolumn{2}{|c|}{3572} & & & & & & \\
\hline $\begin{array}{l}\text { Coast } \\
\text { change }\end{array}$ & \multicolumn{2}{|c|}{-199} & \multicolumn{2}{|c|}{-1043} & \multicolumn{2}{|c|}{116} & & & & & & \\
\hline $\begin{array}{c}\text { Shoal } \\
\text { area } \\
\text { above } \\
\text { chart } \\
\text { datum }\end{array}$ & \multicolumn{2}{|c|}{116} & \multicolumn{2}{|c|}{1389} & \multicolumn{2}{|c|}{-1651} & & & & & & \\
\hline
\end{tabular}


increasing the width of intertidal expose about $0.99 \mathrm{~km}$ as the shoreline is shifting seaward, and the southernmost Ekakula region of the coast shows that gradual increase in intertidal area over about $2.45 \mathrm{~km}$ width, as the shoreline is shifting landward. The emerging composite ebb delta lobes comprises of group of dharma and Maipura islands with an increasing trend to expose intertidal areas to accretion with bed load of sediment. During high tides, the energy of the breaking waves is released higher on the foreshore.

\subsection{Emerging of Ebb Delta of the Coast}

Studying from time series hydrographic datasets mapped using a volumetric depth model and change detection technique on Sufer 8.0 \& ERDAS software spanning three decades (1973-2004), appears rapidly changing erosion and deposition at an accelerate rates (Figure 9). The results show that the maximum changes taking place up to $10 \mathrm{~m}$ contour [12]. The coast profiles and volumetric statistics reveal that the volume increases in deposition during 1983-1992 and drastically during 1992-2002 while during 1973-1983 the erosion in effect. The rate of change of ebb delta of the coast was $150 \mathrm{Ha} / \mathrm{yr}$ during 1973-2002 and the Net area of delta accretion about $4538 \mathrm{Ha}$. The rate of change seems erosion in progress at 5.9 Ha/yr during 1983-1992 otherwise remains in progradation. The nearshore on the southern side of the sheltered sandbars is found to become very shallow causing the waves to break far offshore. A schematic diagram depicting controls on Ebb delta by the regional coastal processes is shown in Figure 10.

\subsection{Spit Dynamics and Offshore Sand Bars}

The changes were accounted from a fixed baseline to tip of the spit at Ekakula region considering past years. The accumulation and expansion of sand-spit at an inlet entrance is varying with time. The updrift bank of the inlet is accreting and extending as a sand-spit in the dominant littoral drift direction [13]. The statistics of spit Geometry for the zones of erosion and accretion were obtained by using query method on Arc GIS intersecting all the layers. Areas of erosion or accretion of the spit geometry changes were shown in Figure 11. The average width derived from area of spit against actual length. The results reveal that the spit was not in stable position and had the asymmetry in its past development. In recent years, it is noticed that altering of spit geometry not only due to cyclonic storms but also to local coastal processes. Post Cyclone storms scenario of 1973, 1982, 1984 and 1985 indicate development of the spit. The maximum spit growth continued unsustainably up to 1987 thereafter detached from the main land due to the effect cyclonic storms of 1988 and 1989. Soon after 1988 cyclone there was a break in the spit that resumed building up until the next cyclonic storm in 1997. This was the period of minimum growth of the spit and continued thereafter during the severe cyclones in 1999 and 2002. These slow expansion rates of sand-spit as a result of inlet with large tidal prisms or strong river flood-generated currents. The growth of a spit is at the expense of the beach to the south of the river mouth. However, during

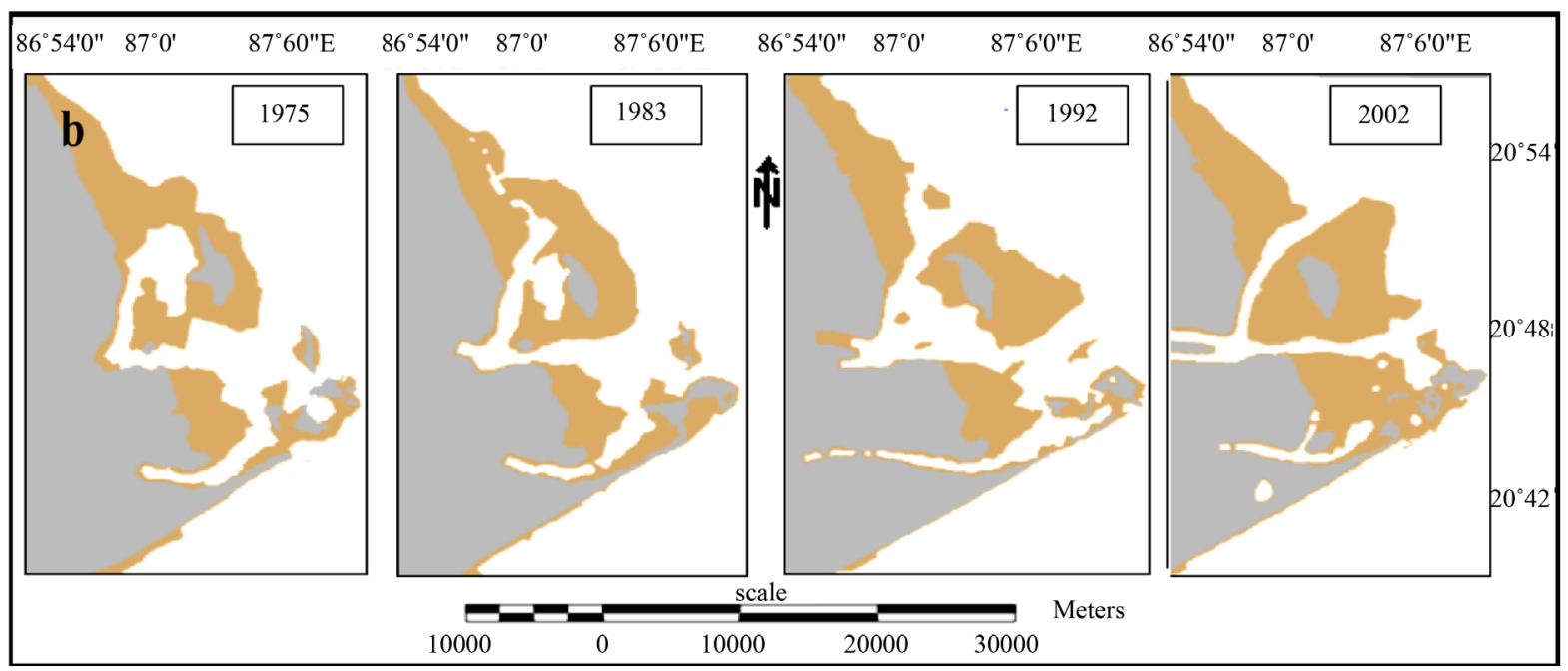

Figure 9. Ebb delta emergence of coast using NHO datasets. 


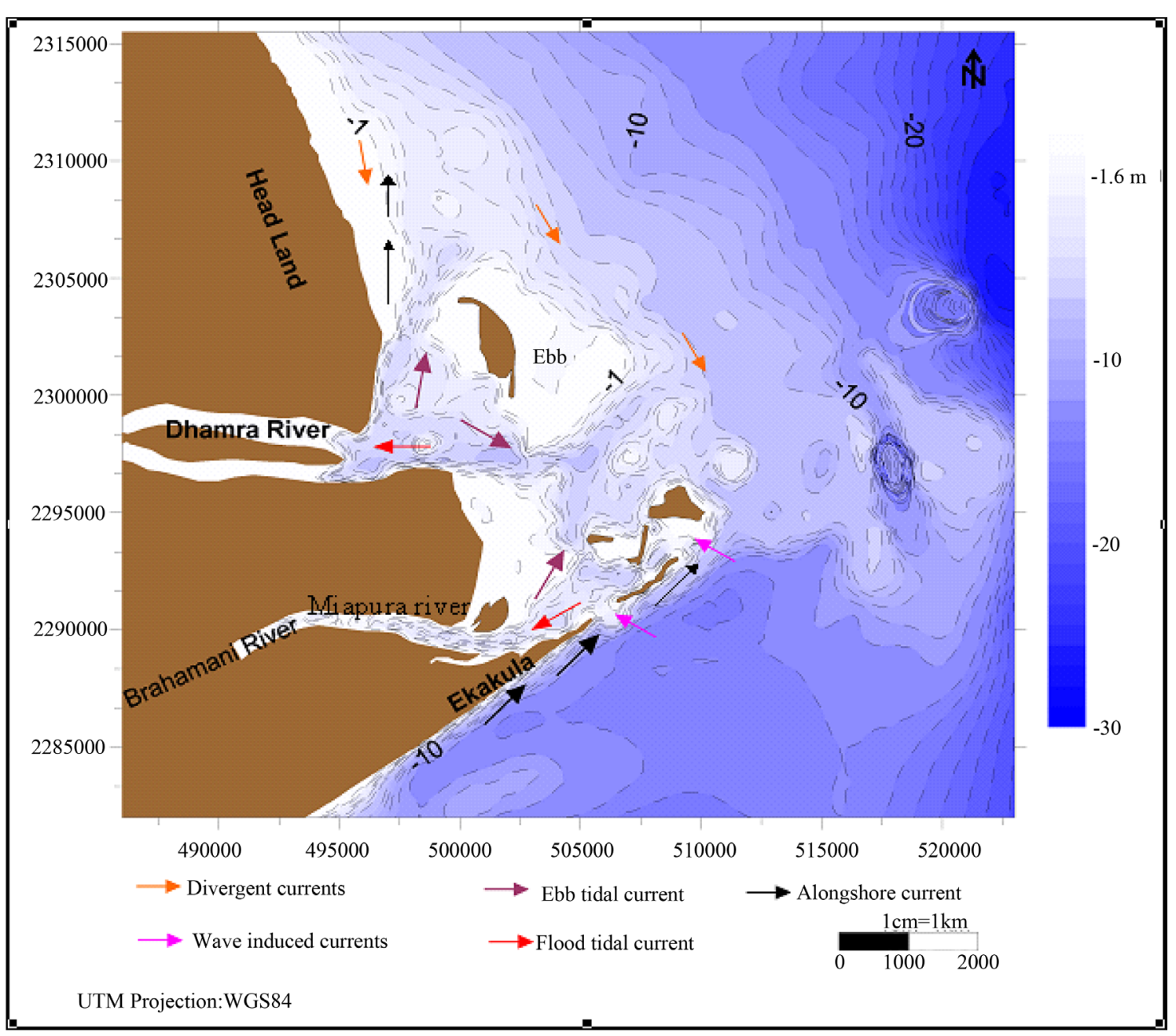

Figure 10. Schematic diagram depicting controls on ebb delta by the reginal coastal processes.

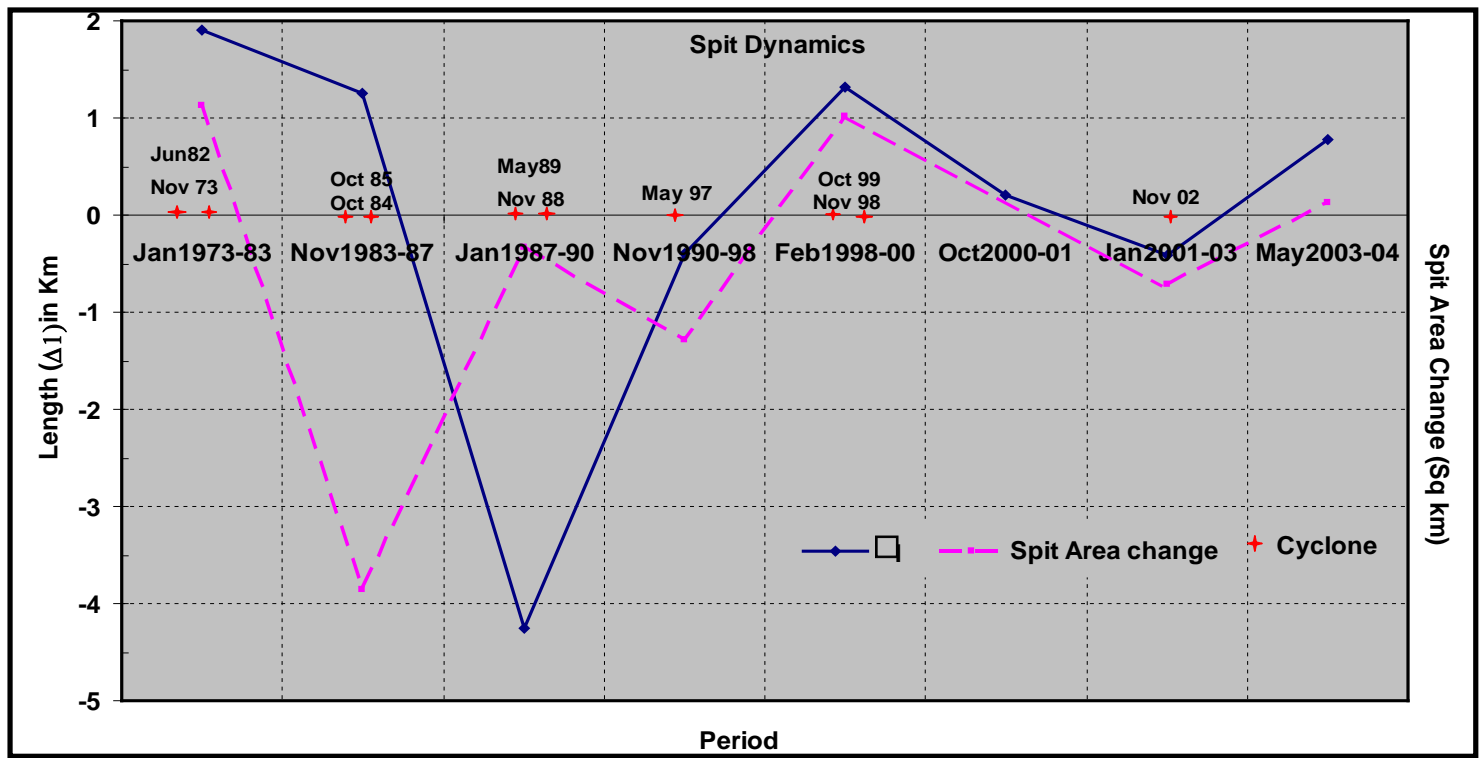

Figure 11. Rate of spit dynamics change at Ekakula region of coast. 
the westerly wave approach (February-April), littoral cells developed in the vicinity of river mouth provided instability to the beach. The off shore sandbar mechanism were observed from a series of satellite images where these exposed to wave attack and, rapidly become emergent and migrate landward into shallow water causes shortening and widening of the bars, which gradually changes into an underdeveloped wave-dominated ebb-tidal delta [14]. The Offshore sand bars become built-in into the sand-spit by initially welding onto the beach, usually on the updrift side. The subsequent landward migration under wave attack changes the bar into sand bodies elongated parallel to the coast.

\subsection{Inlet Morphology Dynamics}

Tidal inlets generally have a short, narrow channel passing between two barrier coastal lands connecting the distributaries (or river) to a sea with strong currents induced by fluvial or tides that supplies sediment. There is a huge amount of sediment discharge by Brahmani-Baitrani river distributaries like Dhamra and Maipura to coast. Dhamra flows via two channels around the Kanika sands seaward side. The northern channel just past the mouth flows in a well defined curved path between mainland and Kanika sands to deeper waters approximately $11 \mathrm{~km}$; another one is east channel $(13 \mathrm{~km})$ located directly in the orientation of east-west direction continues past Kanika sands along its southern shore bifurcating into smaller channels interspaced with sandy shoals. The tidal flows play a very important role to modify the inlet morphology. The ebb tidal current velocity is more than flood tidal currents resulting in shallow bathymetry directly in front of the mouths and sheltered depositional islands [15]. The width of the Dhamra inlet increased from 1.92 to $2.12 \mathrm{~km}$ during 1973-2004 and the bathymetry of mouth changed from narrow to extend coarse up to banks from 2 to $6 \mathrm{~m}$ shown in Table 5. Due to the well defined curved path channels causing coastal barrier land erosion by both bidirectional tidal flows [3].

The Maipura has been extending more into the sea because of narrow elongated spit, Ekakula. Mangrove, tidal creeks and tidal estuary dominate the Maipura region. As there is overwhelming influence of tidal currents and wave induce in these system bypassing sediment pose formation of sand bars. They form shoals at the outer part of this region oriented in EW and NE direction and are exposed in low tide. The bathymetry changes at the mouth of the inlet about $3.5-4.0 \mathrm{~m}$ during 1973-2004 and the width of inlet vary from $1.03-1.00 \mathrm{~km}$ shown in Figure 12.

\section{Conclusion}

The coastal erosion-accretion investigation of the study area spanning past thirty years (1973-2003) addressed in detail locally at specific areas or at regional that reflect natural coastal processes and morphology of the coast. The results show that the erosion-accretion in response to the changing forces, therefore, confirming that the overall coastal environments are dynamic, constantly shaped and reshaped under the influence of both natural processes and anthropogenic modifications. The effect of accretion-erosion process that leading to particular landscape is morphologically dynamic. It is significant to understand degree of the factors that could be responsible for progradation-retrogradation-aggradation of this deltaic coast processes. A module based approach of shoreline change, Intertidal areas of the coast, Emerging of Ebb delta, Spit and offshore sand bars dynamics, Modifications of coastal landforms, Sediment dynamics and Inlet morphology change estimates can be a valuable supplement to the fine coastal dynamic based analysis, since it is able to capture changes all in and around the coast instead of at discrete component analysis. Although Gahirmatha coast is selected for this study, an approach for routine monitoring of coastal erosion and accretion has emerged, which may be applied to study changes in other coastal areas. The detailed studies in this paper will definitely help in better understanding and effective management of the coasts and harbors at the place. Frequent cyclonic wave surges, flooding and close

Table 5. Dimensions of Inlets geometry.

\begin{tabular}{ccccc}
\hline Inlet & 1973 (in km) & 1983 (in km) & 1990 (in km) & 2004 (in km) \\
\hline Dhamra Inlet (W) & 1.92 & 2.01 & 2.08 & 2.12 \\
Maipura Inlet (W) & 1.03 & 1.05 & 1.02 & 1.00 \\
Mangrove Creek & 0.30 & 0.28 & 0.29 & 0.31 \\
North \& East Ebb Channels & & & & $11.00 \& 13.00$ \\
\hline
\end{tabular}



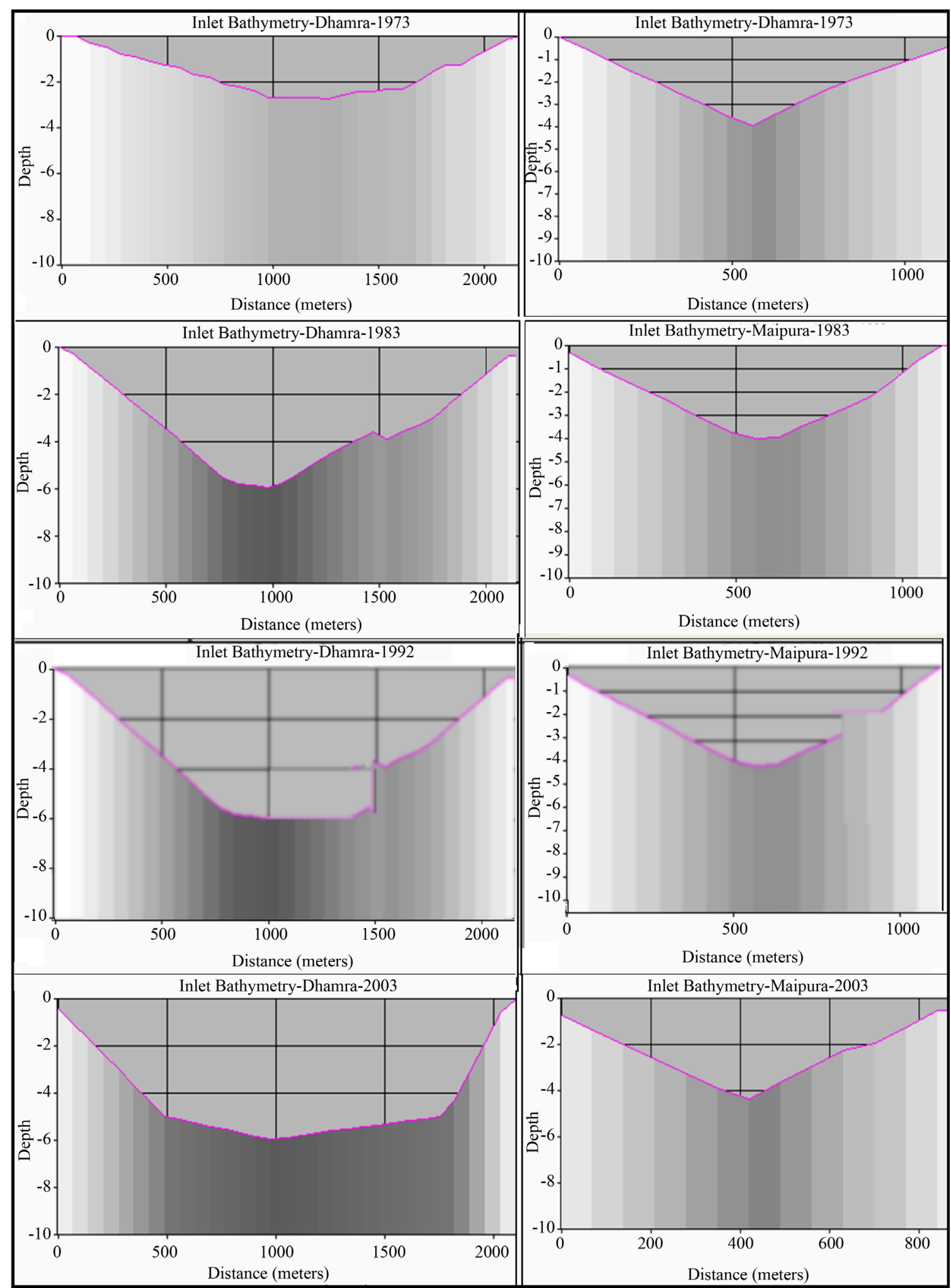

Figure 12. Inlet mouth geometry of delta.

proximity of the dynamic nature to the nearshore features give an understanding of the evolution of modern coastline, morphodynamics of the coast and the sediment depositional behavior due to wave, tide and littoral currents. 


\section{Acknowledgements}

The authors are grateful to the Director NRSC and Head, Oceanography Division, Hyderabad for furnishing the satellite data analysis. Sincere thanks are extended to Department of Science \& Technology, Ministry of Sciences \& Tech., for financial assistance to carry out the SYS-SERC Fast track project and appreciation to the Geomorphology and Remote Sensing Division, AU, who helps me accomplish this study.

\section{References}

[1] Coastal Engineering Research Center (CERC) (1984) Shore Protection Manual. US Army Corps of Engineers, Washington DC, Vol. I, 597, Vol. II, 603.

[2] Coleman, J.M. and Wright, L.D. (1971) Analysis of Major River Systems and Their Deltas: Procedures and Rationale, with Two Examples. Coastal Studies Series 28, Louisiana State University Press, Baton Rouge, 125.

[3] Boyd, R., Dalrymple, R. and Zaitlin, B.A. (1992) Classification of Clastic Coastal Depositional Environments. Sedimentary Geology, 80, 139-150. http://dx.doi.org/10.1016/0037-0738(92)90037-R

[4] Rao, A.D., Sujata Dash, S., Babu, S.V. and Jain, I. (2007) Numerical Modelling of Cyclone’s Impact on the Ocean-A Case Study of the Orissa Susper Cyclone. Journal of Coastal Research, 23, 1245-1250. http://dx.doi.org/10.2112/05-0517.1

[5] Veeranaryana, B., Sridhar, P.N., Sirish Chandra, T., Dhananjaya Rao, E.N., and Satyanarayana Reddy, K. (2009) Hydrodynamic Processes and Heavy Mineral Distribution along Ekakula Beach, Gahirmatha Coast, NE Bay of Bengal. Journal of the Indian Association of Sedimentologists, 28, 85-94.

[6] Dalrymple, R.W. (1992) Tidal Depositional Systems. In: Walker, R.G. and James, N.P., Eds., Facies Models: Response to Sea Level Change, Geological Association of Canada, Newfoundland, 195-218.

[7] Veeranaryana, B., Sridhar, P.N., Raman, I.V., Venkateswara Rao, M., Reddy, K.S.N. and Leach, R. (2009) Mapping Seasonal Suspended Sediments Dynamics and Tidal Propagation in the Coastal Waters of the Bay of Bengal Using Oceansat-I, Ocean Color Monitor data. Journal of the Indian Association of Sedimentologists, 28, 101-106.

[8] Sridhar, P.N., Ramana, I.V., Ali, M.M. and Veeranaryana, B. (2008) Understanding the Suspended Sediment Dynamics in the Coastal Waters of Bay of Bengal Using High Resolution Ocean Colour Data. Current Science, 94, 14991503.

[9] Hema Malini, B. and Nageswara Rao, K. (2004) Coastal Erosion and Habit Loss along the Godavari Delta Front-A Fallout of Dam Construction. Current Science, 87, 1232-1236.

[10] Trenhaile, A.S. (1997) Coastal Dynamics and Landforms. Clarendon Press, Oxford, 366-372.

[11] IPCC Report (2001) Intergovernmental Panel on Climate Change. Washed off the Map 25 November 2000, Fred Pearce, Magazine Issue 2266.

[12] Veeranaryana, B., Sridhar, P.N., Koteswara Rao, K., Satyanarayana, G. and Rao, E.N.D. (2011) Effect of the Bathymetric Changes on Hydrodynamic Processes and Morphology at the Inlets of Gahirmatha Coast, NE Bay of Bengal. International Journal of Earth Sciences and Engineering, 4, 56-70.

[13] Manimurali, R. and Vethmon, P. (2013) Morphodynamic Evolution of Ekakula Spit of Odisha Coast, India Using Satellite Data. Indian Journal of Marine Sciences, 43, 1131-1136.

[14] Oertel, G.F. (1975) Ebb-Tidal Deltas of Georgia Estuaries. Geology and Engineering, Academic Press, New York, 267-276. http://dx.doi.org/10.1016/b978-0-12-197502-9.50021-6

[15] Tarang Khangaonkar., Felix Kristanovich., Mizan Rashid and Bankim Mallick. (1998) Tidal Circulation and Sediment Transport Modeling for Port Dhamre Chandbali Expansion Project. Technical Papers, Port Dhamra Documents. 